\title{
Up-regulation of Heme Oxygenase-1 by Korean Red Ginseng Water Extract as a Cytoprotective Effect in Human Endothelial Cells
}

\author{
Hana Yang ${ }^{1}$, Seung Eun Lee ${ }^{1}$, Seong Il Jeong ${ }^{1}$, Cheung-Seog Park ${ }^{1}$, Young-Ho Jin ${ }^{2}$, \\ and Yong Seek Park ${ }^{1^{*}}$ \\ ${ }^{1}$ Department of Microbiology, Kyung Hee University School of Medicine, Seoul 130-701, Korea \\ ${ }^{2}$ Department of Physiology, Kyung Hee University School of Medicine, Seoul 130-701, Korea
}

\begin{abstract}
Korean red ginseng $(\mathrm{KRG})$ is used worldwide as a popular traditional herbal medicine. KRG has shown beneficial effects on cardiovascular diseases, such as atherosclerosis, diabetes, and hypertension. Up-regulation of a cytoprotective protein, heme oxygenase (HO)-1, is considered to augment the cellular defense against various agents that may induce cytotoxic injury. In the present study, we demonstrate that KRG water extract induces HO-1 expression in human umbilical vein endothelial cells (HUVECs) and possible involvement of the anti-oxidant transcription factor nuclear factor-eythroid 2-related factor 2 (Nrf2). KRG-induced HO-1 expression was examined by western blots, reverse transcriptase polymerase chain reaction and immunofluorescence staining. Specific silencing of Nrf2 genes with Nrf2-siRNA in HUVECs abolished HO-1 expression. In addition, the HO inhibitor zinc protoporphyrin blunted the preventive effect of $\mathrm{KRG}$ on $\mathrm{H}_{2} \mathrm{O}_{2}$-induced cell death, as demonstrated by terminal transferase dUTP nick end labeling assay. Taken together, these results suggest that KRG may exert a vasculoprotective effect through Nrf2mediated HO-1 induction in human endothelial cell by inhibition of cell death.
\end{abstract}

Keywords: Panax ginseng, Endothelial cells, Heme oxygenase, Oxidative stress, Vascular diseases

\section{INTRODUCTION}

Endothelium is a monolayer of endothelial cells lining the entire vascular system. The vascular endothelium plays an important role in regulation of thrombotic response, modulation of vascular tone and blood flow, and regulation of immune and inflammatory responses by controlling interactions between immune cells and the vessel wall [1].

Vascular injury, including structural and functional impairment of endothelium, plays a key role in the pathogenesis of various vascular diseases, such as atherosclerosis, diabetes, and hypertension. Chronic damage to endothelium causes accumulation of lipid and increased

(c) This is an Open Access article distributed under the terms of the Creative Commons Attribution Non-Commercial License (http://creativecommons.org/licenses/by-nc/3.0/) which permits unrestricted non-commercial use, distribution, and reproduction in any medium, provided the original work is properly cited. adhesion of monocytes and platelets [2]. Furthermore, injured endothelial cells release several growth factors, leading to later migration and proliferation of smooth muscle cells $[3,4]$. Finally, these changes in the vessel wall could accelerate atherosclerotic plaque formation.

Korean red ginseng (KRG) is used as a well-known herbal medicine as well as a wide range of food products, including beverages, candy, jellies, and snacks. Biological properties of KRG have been extensively investigated as its consumption has been increasing. Ginseng is thought to exert various effects, including anti-oxidant, anti-thrombotic, anti-hyperlipidemic, and anti-cancer

Received 21 Mar. 2011, Revised 16 Jun. 2011, Accepted 16 Jun. 2011

*Corresponding author
E-mail: yongseek@khu.ac.kr
Tel: +82-2-961-0296, Fax: +82-2-962-6189 
effects [3-6]. Recently, the interest of researchers has focused on the vascular protective effect of KRG. In endothelial cells, KRG eliminates generation of NADPHdriven superoxide [7] and increases nitric oxide synthase activity and nitric oxide concentrations, conferring a hypotensive effect [8]. Previous studies have also reported that $\mathrm{KRG}$ promotes endothelial proliferation and protects $\mathrm{H}_{2} \mathrm{O}_{2}$-induced cell death $[9,10]$. Due to its vascular protective effect, KRG is believed to be beneficial for cardiovascular diseases such as atherosclerosis, diabetes, and hypertension [11-13].

Heme oxygenase (HO) is a cytoprotective protein that catalyzes heme degradation, yielding carbon monoxide (CO), iron, and biliverdin as the final products. There are three isoforms of $\mathrm{HO}$ in mammals: HO-1, HO-2, and HO-3 $[14,15]$. In particular, HO-1 is well known as a protective enzyme with anti-oxidant, anti-apoptotic, and anti-inflammatory effects [16]. HO-1 is a stress inducible protein. Various stimuli, such as thiol scavengers, ultraviolet radiation, and oxidative stress act as inducers of HO-1 [17]. In general, these stimuli cause generation of reactive oxygen species (ROS), which could activate an adaptive response of HO-1. Up-regulation of HO-1 exerts cytoprotective effects due to activity of its products, including $\mathrm{CO}$ and/or bilirubin, formed from biliverdin by the activity of biliverdin reductase [18,19]. HO-1 has a beneficial role in several clinically relevant diseases. There also is increasing evidence to show that HO-1 is associated with vascular disease, such as atherosclerosis, diabetes, and hypertension [20]. HO-1, which is highly expressed in vascular tissues, protects against vasculopathy and confers a cytoprotective function in the circulation [21]. In human endothelial cells, HO-1 deficiency results in tumor necrosis factor- $\alpha$ and interleukin- $1 \alpha$ mediated endothelial damage [22]. These results suggest that HO-1 may play an important role in sustaining the health of the vascular system.

In this study, we examined the cardiovascular protective effect of HO-1 induced by KRG water extract in human umbilical vein endothelial cells (HUVECs). In addition, we investigated involvement of nuclear factorerythroid 2-related factor 2 ( Nrf2) in induction of HO-1 and the cytoprotective effect of HO-1 in HUVECs.

\section{MATERIALS AND METHODS}

\section{Materials}

Korean red ginseng powder was obtained from the Korea Ginseng and Tobacco Central Research Institute (Daejen, Korea). M199 medium and fetal bovine serum were purchased from Welgene Inc. (Daegu, Korea). TRIzol reagent was supplied by Invitrogen (Carlsbad, CA, USA). Zinc protoporphyrin (ZnPP) was provided from Sigma Chemical (St. Louis, MO, USA). TransPass R2 Transfection Reagent was obtained from New England Biolabs (Hercules, CA, USA). Anti-Nrf2 and anti-Lamin B were purchased from Santa Cruz Biotechnology (Santa Cruz, CA, USA). Anti-HO-1 was obtained from Epitomics (Burlingame, CA, USA). Anti-GAPDH was supplied by AbFrontier (Seoul, Korea). All other chemicals and reagents were of analytical grade.

\section{Preparation of red ginseng water extract}

For preparation of red ginseng water extract, we modified a method used in a previous study [23]. Korean red ginseng powder was soaked in water $(1: 25, \mathrm{~W}: \mathrm{W})$ for $3 \mathrm{~h}$, then boiled for $40 \mathrm{~min}$. Following centrifugation at 3,000 rpm for $60 \mathrm{~min}$, supernatants of ginseng extract were further centrifugated at $10,000 \mathrm{~g}$ for $30 \mathrm{~min}$ and lyophilized. Ginseng extracts were dissolved in pure water immediately prior to the experiment.

\section{Cell culture}

HUVECs were maintained in M199 medium and supplemented with $10 \%$ fetal bovine serum, $1 \%$ penicillin and streptomycin, $10 \mathrm{ng} / \mathrm{mL}$ human fibroblast growth factor, and $18 \mathrm{mU} / \mathrm{mL}$ heparin. The cells were incubated at $37^{\circ} \mathrm{C}$ under $5 \% \mathrm{CO}_{2}$ atmosphere. HUVECs were grown to approximately $80 \%$ confluence, maintained with fresh medium described above, and subcultured every 2 to $3 \mathrm{~d}$. The cells were used within passages 4 to 9 during these experiments [24].

\section{Western blot analysis}

We applied $20 \mu \mathrm{g}$ of the whole cell lysate proteins to each lane and analyzed them with western blots. Western blot analysis was performed using monoclonal antibody against mouse HO-1 and monoclonal antibody against mouse glyceraldehyde-3-phosphate dehydrogenase. Horseradish peroxidase-conjugated anti-IgG antibodies were used as the secondary antibody to detect the abovementioned protein bands by enhanced chemiluminescence WESTSAVE-Up ${ }^{\mathrm{TM}}$ (Abfrontier, Seoul, Korea).

\section{RNA isolation and reverse transcriptase-poly- merase chain reaction}

Cells were seeded in a $100 \mathrm{~mm}$-diameter plate containing M199 medium. After 24 h, KRG was treated to a 
final concentration of $0.5 \mathrm{mg} / \mathrm{mL}$ and the cells were incubated for $18 \mathrm{~h}$. RNA extraction was achieved using $1 \mathrm{~mL}$ TRIzol reagent. The RNA pellets were washed in 70\% ethanol, dried completely, and dissolved in diethylpyrocarbonate to inhibit RNase. Total RNA was quantified using a ND-100 spectrometer (NanoDrop Technologies, Wilmington, DE, USA). Polymerase chain reaction was performed using the synthesized cDNA as a template and using specific primers for $\mathrm{HO}-1$ or $\beta$-actin as a loading control. The primer sequence for human HO-1 was 5'-ACATCTATGTGGCCCTGGAG-3' (forward) and 5'-TGTTGGGGAAGGTGAAGAAG-3' (reverse). The amplified products were resolved by $1 \%$ agarose gel electrophoresis, stained with ethidium bromide, and photographed under ultraviolet light.

\section{Immunofluorescence staining}

HUVECs were cultured in a glass culture chamber slide (Falcon Plastics Inc., London, ON, Canada) and processed for immunofluorescence analysis. Immunofluorescence method as described previously method [25].

\section{Nuclear factor-eythroid 2-related factor 2 silenc- ing by siRNA}

The cells were seeded on six-well plates at a density of $2 \times 10^{5}$ cells/well in $2 \mathrm{~mL}$ of complete M199 medium. Cells were allowed to grow to $60 \%$ to $80 \%$ confluence before transfection with siRNA (SC-37049, Santa Cruz Biotechnology). For each transfection, 1,200 $\mu \mathrm{L}$ of the transfection medium was added with siRNA duplex/ transfection reagent mix (TransPass $\mathrm{R} 2$ solution $\mathrm{A}+\mathrm{B}$ ), and the entire volume was added gently to the cells [26].

\section{Measurement of intracellular reactive oxygen spe- cies generation}

Intracellular ROS in $\mathrm{H}_{2} \mathrm{O}_{2}$ stimulated HUVECs is analyzed using DCF/DA staining. HUVECs were plated at a density of $4 \times 10^{5}$ cells in $60 \mathrm{~mm}$ dishes. After $18 \mathrm{~h}$ incubation with $\mathrm{KRG}$ in the presence or absence of $1 \mu \mathrm{M}$ $\mathrm{ZnPP}$, cells were stained with $10 \mu \mathrm{M}$ DCF/DA for 55 min, and then stimulated with $500 \mu \mathrm{M} \mathrm{H}_{2} \mathrm{O}_{2}$ for $5 \mathrm{~min}$. After rinsing with PBS, the cells were examined by fluorescence microscopy.

\section{Terminal transferase dUTP nick end labeling assay}

Cells $\left(2 \times 10^{4}\right.$ cells $/ 300 \mu \mathrm{L} /$ well $)$ were seeded in an 8 -well chamber slide and were washed with phosphatebuffered saline (PBS) and fixed in 4\% formaldehyde for $1 \mathrm{~h}$ and then exposed permeabilizing solution $(0.1 \%$ Triton $\mathrm{X}-100$ in $0.1 \%$ sodium citrate buffer) for $2 \mathrm{~min}$ at $4^{\circ} \mathrm{C}$.
Cells were incubated with the terminal transferase dUTP nick end labeling (TUNEL) reaction mixture (Roche, Mannheim, Germany) for $1 \mathrm{~h}$ at $37^{\circ} \mathrm{C}$ in the dark. After rinsing with PBS, the cells were mounted and examined by fluorescence microscopy.

\section{Statistical analysis}

Statistical significance was estimated by student's $t$ test and the results were expressed as mean $\pm \mathrm{SD}$.

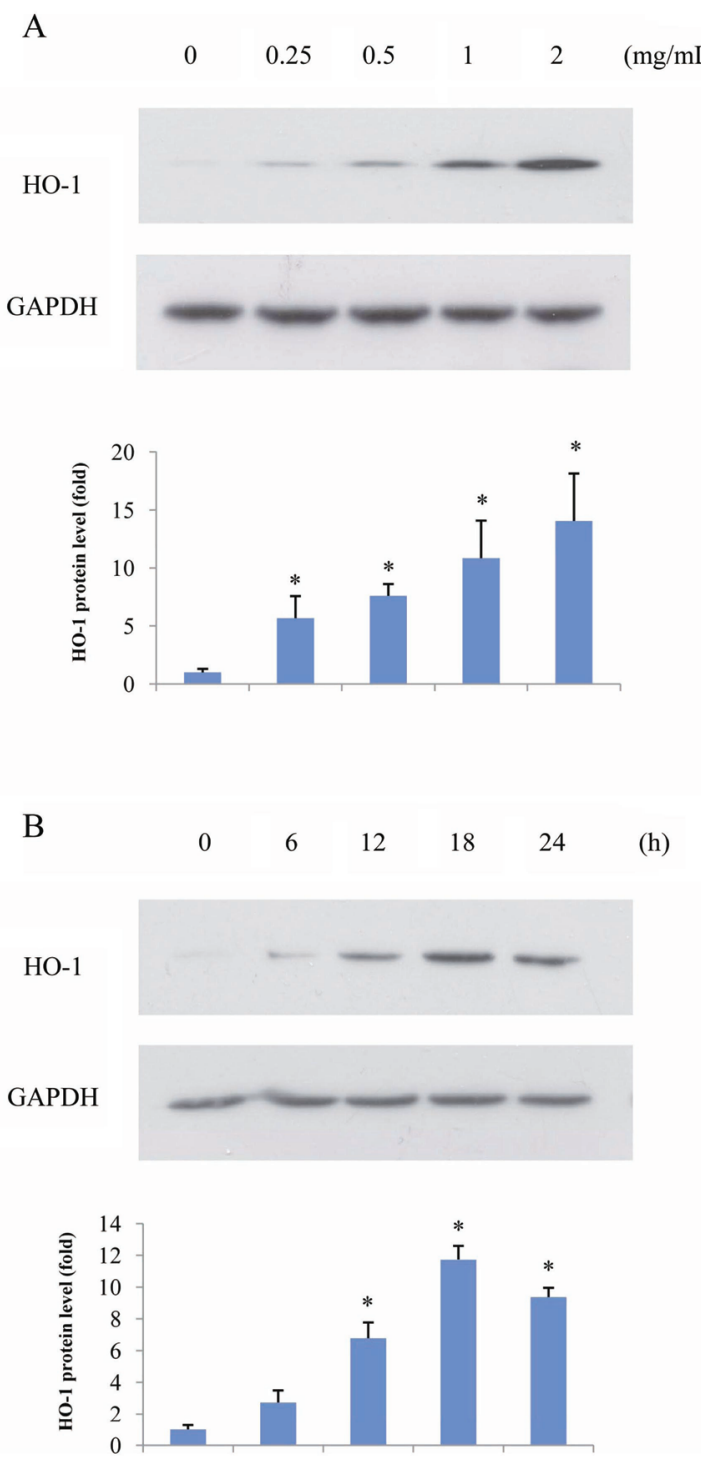

Fig. 1. Induction of heme oxygenase (HO)-1 protein by Korean red ginseng (KRG) in human umbilical vein endothelial cells (HUVECs). After treatment of HUVECs with various concentrations of KRG (A) at various time intervals (B), cell lysates were prepared and $20 \mu \mathrm{g}$ samples of proteins were subjected to western blotting using the anti$\mathrm{HO}-1$ antibody and anti-glyceraldehyde-3-phosphate dehydrogenase (GAPDH) antibody as a loading control. Representative data from three independent experiments is shown. ${ }^{*} p<0.05$. 
A

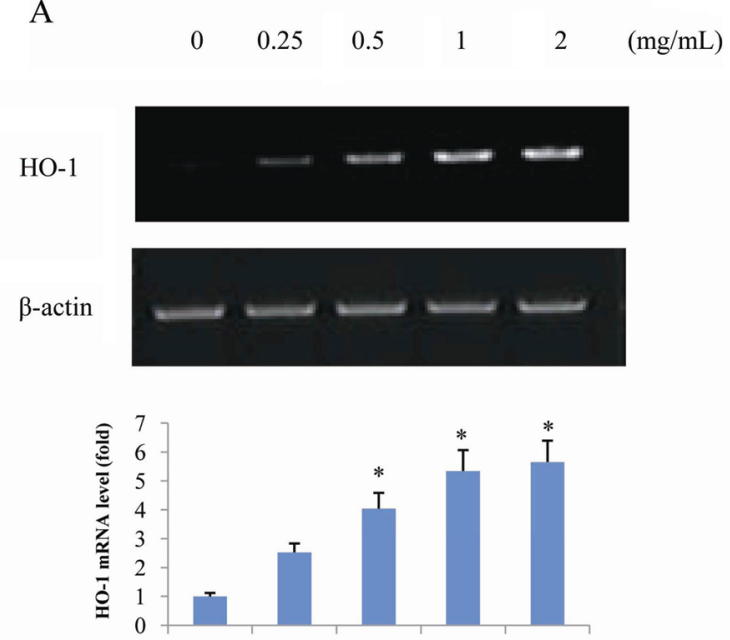

B

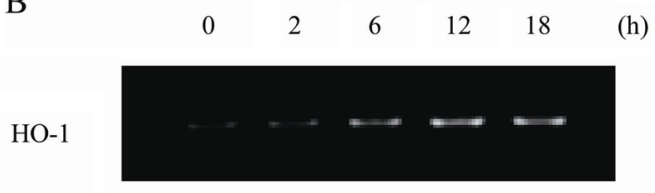

$\beta$-actin
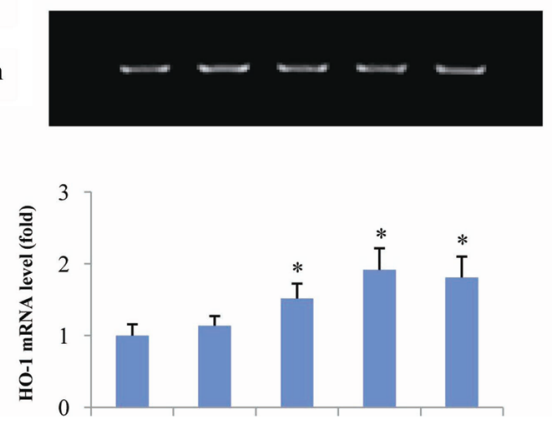

Fig. 2. Induction of heme oxygenase (HO)-1 mRNA by Korean red ginseng (KRG) in human umbilical vein endothelial cells (HUVECs). After treatment of HUVECs with various concentrations of KRG (A) at various time intervals $(B)$, cell lysates were prepared. The total RNA was extracted and analyzed by reverse transcriptase polymerase chain reaction (RT-PCR). The amplified RT-PCR product was visualized on $1 \%$ agarose gel. Representative data from three independent experiments is shown. ${ }^{*} p<0.05$.

\section{RESULTS}

Effects of heme oxygenase- 1 induction by Korean red ginseng in human umbilical vein endothelial cells

Up-regulation of HO-1 expression plays an important role in protecting cells against oxidative stress. We first demonstrated the effect of various concentrations of KRG on HO-1 induction. KRG increased HO-1 protein expression in a concentration-dependent manner (Fig. 1A). Cells were incubated with various concentrations
Control
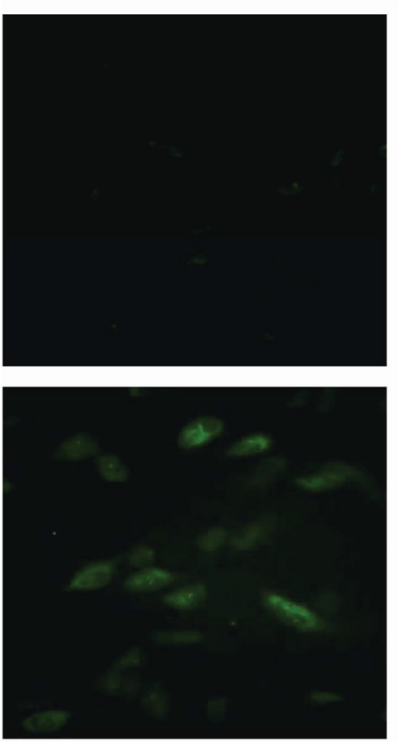

KRG $0.5 \mathrm{mg} / \mathrm{mL}$
KRG $0.25 \mathrm{mg} / \mathrm{mL}$
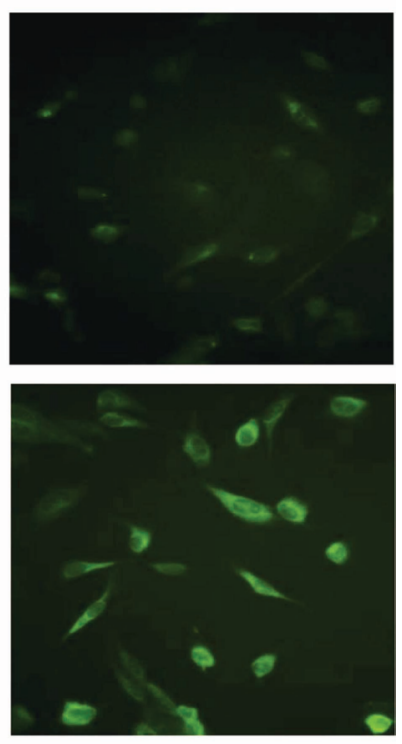

KRG $2 \mathrm{mg} / \mathrm{mL}$

Fig. 3. Immunofluorescence staining analysis of heme oxygenase (HO)-1 expression in human umbilical vein endothelial cells. Cells were pre-treated with various concentrations of Korean red ginseng (KRG) for $18 \mathrm{~h}$. They were fixed and HO-1 localization was determined by immunofluorescence staining with an anti-HO-1 antibody followed by a fluorescence-tagged secondary antibody.

of KRG for $18 \mathrm{~h}$. Treatment of cells with KRG $(0.5 \mathrm{mg}$ / $\mathrm{mL}$ ) also resulted in time-dependent increases in HO-1 protein expression in HUVECs (Fig. 1B). KRG also increased the HO-1 mRNA level, as demonstrated in Fig. 2. After incubation with various concentrations of KRG for $12 \mathrm{~h}$, the HO-1 mRNA level increased in a concentrationdependent manner (Fig. 2A). KRG-treated HUVECs showed the HO-1 mRNA level in a time-dependent manner (Fig. 2B).

Immunofluorescence staining of heme oxygenase-1 in human umbilical vein endothelial cells

After KRG treatment, cells were fixed, and HO-1 localization in HUVECs was observed by immunofluorescence staining with an anti-HO-1 antibody, followed by a fluorescence-tagged secondary antibody. Immunofluorescence analysis showed that HO-1 protein levels were increased in HUVECs after treatment with KRG in a concentration-dependent manner (Fig. 3).

Nuclear factor-eythroid 2-related factor 2 siRNA blocks Korean red ginseng-induced heme oxygenase-1 protein expression

HO-1 is one of the major genes encoding phase II 


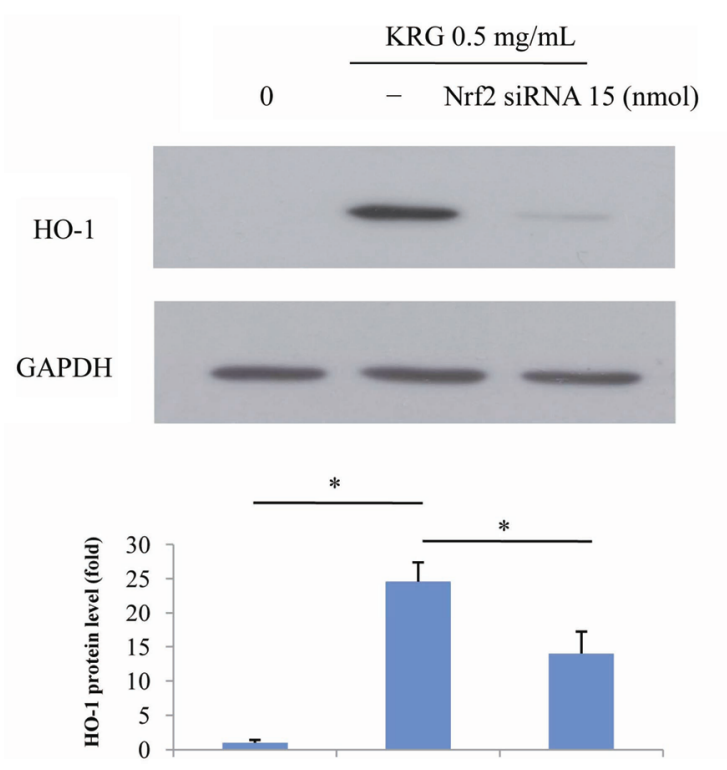

Fig. 4. Inhibition of heme oxygenase (HO)-1 expression by nuclear factor-eythroid 2-related factor 2 (Nrf2) siRNA in human umbilical vein endothelial cells (HUVECs). Cells were treated with Korean red ginseng (KRG) at the indicated concentration for $18 \mathrm{~h}$. Transient transfection of HUVECs with Nrf2 siRNA inhibited expression of the HO-1 protein. A volume of $15 \mathrm{nmol}$ of Nrf2 siRNA abrogates KRG-induced HO-1 up-regulation. Representative data from three independent experiments is shown. GAPDH, glyceraldehyde3-phosphate dehydrogenase. ${ }^{*} p<0.05$.

detoxifying and anti-oxidant enzymes and is widely distributed in mammalian tissues. It is modulated by the Nrf2/Keap1 transcription factor system [27]. Thus, we attempted to determine whether KRG could activate Nrf2 in association with HO-1 up-regulation. For this, siRNA of Nrf2 was employed. With $15 \mathrm{nmol}$ of Nrf2 siRNA, the increase in HO-1 protein was abolished (Fig. 4). These results indicate a key role for Nrf2 in regulation of KRGinduced HO-1 protein expression in HUVECs.

\section{Protection against oxidative stress provided by heme oxygenase- 1 induced by Korean red ginseng}

ROS acts as a secondary messenger that mediates the signal network involved in growth, survival, and death. In particular, a number of evidences support that ROS that causes oxidative stress may play an essential role in mediating cell death in endothelial cells. To clarify whether KRG-induced HO-1 plays a significant role in ROS scavenging, which attenuates endothelial cell death, we conduct DCF/DA staining that detects intracellular ROS level (Fig. 5). An increase in intracellular ROS was observed in $\mathrm{H}_{2} \mathrm{O}_{2}$-stimulated cells. ROS generation was reduced by KRG treatment and reversed by $\mathrm{ZnPP}$, the specific HO-1 inhibitor. These results imply that HO-1

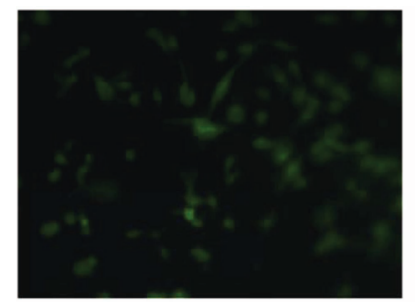

Control

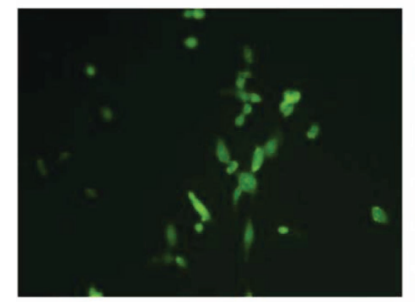

$\mathrm{H}_{2} \mathrm{O}_{2}+\mathrm{KRG} 0.5$

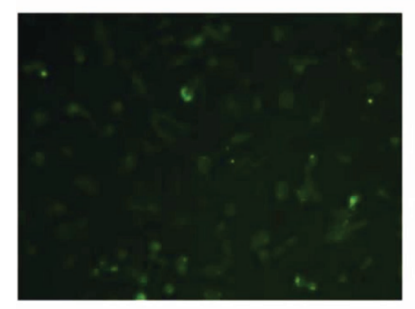

$\mathrm{H}_{2} \mathrm{O}_{2}+\mathrm{KRG} 1$

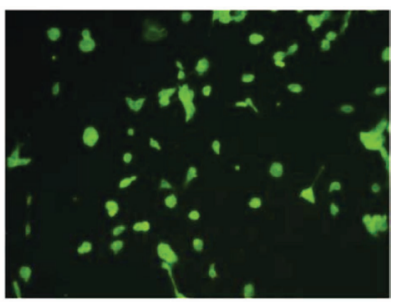

$\mathrm{H}_{2} \mathrm{O}_{2}$

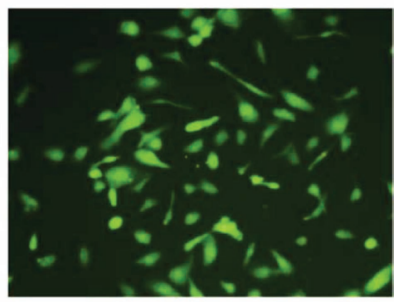

$\mathrm{H}_{2} \mathrm{O}_{2}+\mathrm{KRG} 0.5+\mathrm{ZnPP}$

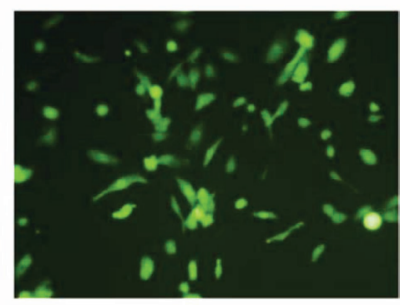

$\mathrm{H}_{2} \mathrm{O}_{2}+\mathrm{KRG} 1+\mathrm{ZnPP}$
Fig. 5. Intracellular reactive oxygen species level of Korean red ginseng (KRG)-treated human umbilical vein endothelial cells (HUVECs). KRG (0.5 or $1 \mathrm{mg} / \mathrm{mL}$ ) stimulated HUVECs were pre-treated for $1 \mathrm{~h}$ with or without $1 \mu \mathrm{M}$ zinc protoporphyrin (ZnPP). After $18 \mathrm{~h}$ incubation, HUVECs were treated with DCF/DA for 55 min, followed by the treatment with $100 \mu \mathrm{M} \mathrm{H}_{2} \mathrm{O}_{2}$ for $5 \mathrm{~min}$. The protective effect of $\mathrm{KRG}$ on $\mathrm{H}_{2} \mathrm{O}_{2}$-induced cell death and its blockage by $\mathrm{HO}-1$ inhibitor were observed by fluorescence microscopy.

induction by KRG prevents ROS production and by extension, ROS-mediated cell damage and/or death.

\section{Increase of endothelial cell death by pharmaco- logical inhibition of heme oxygenase-1}

Endothelial damage has been thought to be the initial cause of development of vascular disorders. A previous study suggested that protection in human endothelial cells by blockade of oxidative stress could be an effective strategy in treatment of atherosclerosis [28]. To determine whether KRG-induced HO-1 up-regulation is responsible for the preventive effect of endothelial cell injury, we inhibited HO-1 enzymatic activity through treatment with the specific HO-1 inhibitor, ZnPP. KRG-stimulated cells were pre-incubated with or without $1 \mu \mathrm{M} \mathrm{ZnPP}$, and cell death was measured by an in situ TUNEL assay. The TUNEL assay indicates cell death, including apoptosis, by detection of fragmented DNA. As illustrated in Fig. 6, 

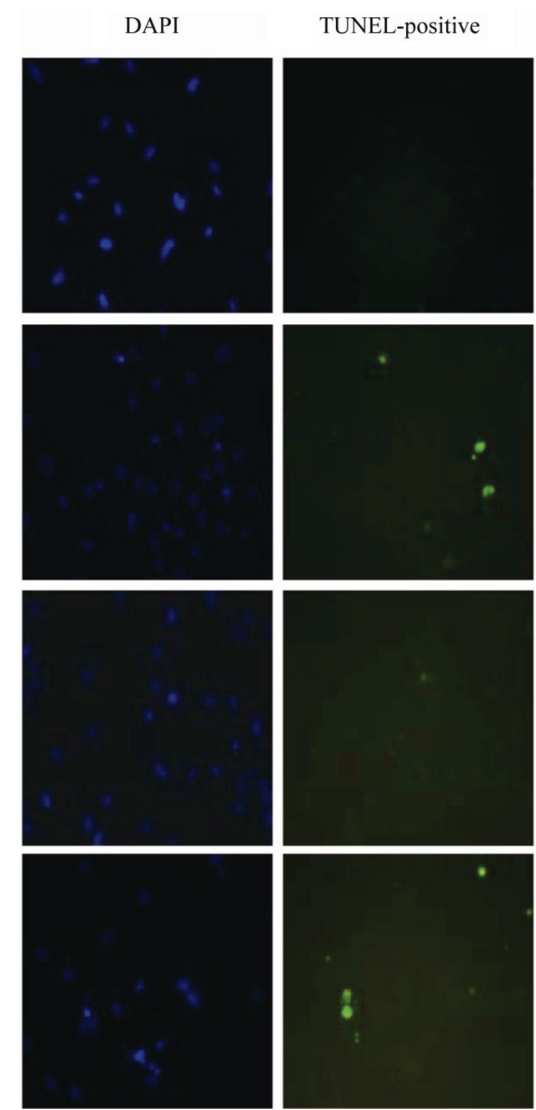

Control
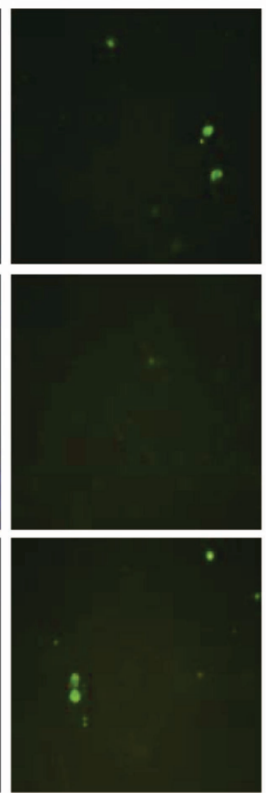

$\mathrm{KRG}+\mathrm{H}_{2} \mathrm{O}_{2}$

$\mathrm{KRG}+\mathrm{ZnPP}+\mathrm{H}_{2} \mathrm{O}_{2}$

Fig. 6. Terminal transferase dUTP nick end labeling (TUNEL) assay of heme oxygenase ( $\mathrm{HO})-1$ inhibition in Korean red ginseng (KRG)-treated human umbilical vein endothelial cells (HUVECs). KRG $(0.5 \mathrm{mg} / \mathrm{mL})$ stimulated HUVECs were pre-treated for $1 \mathrm{~h}$ with $1 \mu \mathrm{M}$ zinc protoporphyrin ( $\mathrm{ZnPP}$ ), followed by treatment with $100 \mu \mathrm{M}$ $\mathrm{H}_{2} \mathrm{O}_{2}$. After $18 \mathrm{~h}$ incubation, the protective effect of $\mathrm{KRG}$ on $\mathrm{H}_{2} \mathrm{O}_{2}$ induced cell death in HUVECs and its blockage by HO-1 inhibitor were determined by the TUNEL assay. DAPI, 4',6-diamidino-2-phenylindole.

$\mathrm{H}_{2} \mathrm{O}_{2}$ treatment significantly increased TUNEL-positive cells, which was restored by KRG. However, ZnPP pretreatment diminished the cytoprotective effect of $\mathrm{KRG}$ in $\mathrm{H}_{2} \mathrm{O}_{2}$-induced cell death. These results strongly suggest that the vascular protective effect of KRG is mediated by HO-1 activity.

\section{DISCUSSION}

In the present study, we investigated the induction of a cytoprotective enzyme, HO-1, by KRG water extract in human endothelial cells. We show that KRG increased both mRNA and the protein level of HO-1 and its cytoprotective effect in HUVECs.

Ginseng has been used for treatment of various diseases, including cardiovascular disorders, in East Asia for over 2,000 yr and has become the most famous medicinal plant in the world. KRG is prepared from fresh ginseng steamed and sun-dried. Under high pressure and high temperature, several components in ginseng could be chemically transformed, inducing better pharmacological activity, such as the anti-oxidant, anti-carcinogenic, and ameliorative effect on blood circulation, than white ginseng [29,30]. These changed constituents are mostly triterpene glycosides, called ginsenosides, which are major active ingredients of ginseng. Recently, the diverse effects of ginsenosides on endothelial cells have been extensively studied. Ginsenoside $\operatorname{Rg}_{3}$ has anti-inflammatory and anti-atherosclerotic activities by reduction of cell adhesion molecules and pro-inflammatory cytokines in human endothelial cells [31]. It also prevents endothelial cell death via inhibition of the mitochondrial apoptotic signaling pathway [32]. Another ginsenoside $R b_{1}$, is also one of the major constituents of ginseng. Its cytoprotective effect in oxidized low-density lipoprotein-injuring endothelial cells has been previously studied in vitro [33]. Ginsenoside $\mathrm{Rg}_{1}$ induces vascular endothelial growth factor expression in human endothelial cells, which regulates proliferation and migration of endothelial cells [34]. Ginsenoside protopanaxatriol has been reported to prevent $\mathrm{H}_{2} \mathrm{O}_{2}$-induced endothelial cell death by modulation of intracellular redox status [10]. Other constituents of red ginseng include brown reaction products. Browning pigments in ginseng extract are increased when ginseng is steamed at $100^{\circ} \mathrm{C}$, almost all of which are water soluble [35]. Water soluble browning reaction products isolated from KRG have been reported to have anti-oxidative effects due to their free radical scavenging activity [36]. It is assumed that the protective effect of KRG is attributed to the anti-oxidant and anti-apoptotic activity of these active components.

HO-1 has a key role in the cellular defense mechanism against oxidative stress generated by ROS. Increase of HO-1 activity protects against oxidative damage-induced cell death via the mechanism associated with free heme catabolism by HO-1 [37]. Numerous studies have supported the suggestion that anti-cell death activity of HO-1 represents its cytoprotective roles in the vascular system. A study of angiogenesis revealed that overexpression of HO-1 enhanced endothelial cell proliferation [38]. The beneficial effect of HO-1 is mediated by the actions of its byproducts, $\mathrm{CO}$ and bilirubin. $\mathrm{CO}$ changes blood fluidity and blood flow by modulation of vasomotor tone, vascular smooth muscle cell proliferation, and platelet agglutination [21]. Bilirubin exerts a vascular protective effect by preservation of EC integrity, prevention of EC death, and increase of vascular reactivity [39].

Previous evidence has indicated that HO-1 expression 
may be controlled at the transcriptional level by KRG. Hwang and Jeong [40] revealed that a key ginsenoside, $\mathrm{Rb}_{1}$, induced HO-1 expression via Nrf2 and ARE pathways in 6-OHDA-treated human dopaminergic cells. Nrf2-mediated HO-1 induction by red ginseng extract in rat pheochromocytoma cells has also been reported [41]. However, there have been no reports revealing the mechanism underlying KRG induced HO-1 induction in human endothelial cells. We have determined that the major transcription factor of anti-oxidant gene Nrf2 is involved in this induction of HO-1 in HUVECs, confirming RNAi-mediated gene silencing. As mentioned above, Nrf2 promotes HO-1 expression induced by several ginseng constituents in various cell lines. Therefore, the transcriptional activation of Nrf2 following KRG water extract treatment may be associated with a noticeable increase in HO-1 expression in HUVECs.

In this study, we suggest that KRG water extract may exert a cytoprotective effect through HO-1 induction and that this up-regulation of HO-1 in HUVECs is mediated by the transcription factor Nrf2. This study supports a possible therapeutic mechanism of KRG in cardiovascular diseases.

\section{ACKNOWLEDGEMENTS}

This research was supported by Basic Science Research Program through the National Research Foundation of Korea (NRF) funded by the Ministry of Education, Science and Technology (2010-0005872).

\section{REFERENCES}

1. Sumpio BE, Riley JT, Dardik A. Cells in focus: endothelial cell. Int J Biochem Cell Biol 2002;34:1508-1512.

2. Ip JH, Fuster V, Badimon L, Badimon J, Taubman MB, Chesebro JH. Syndromes of accelerated atherosclerosis: role of vascular injury and smooth muscle cell proliferation. J Am Coll Cardiol 1990;15:1667-1687.

3. Park BJ, Lim YS, Lee HJ, Eum WS, Park J, Han KH, Choi SY, Lee KS. Anti-oxidative effects of Phellinus linteus and red ginseng extracts on oxidative stressinduced DNA damage. BMB Rep 2009;42:500-505.

4. Jin YR, Yu JY, Lee JJ, You SH, Chung JH, Noh JY, Im JH, Han XH, Kim TJ, Shin KS et al. Antithrombotic and antiplatelet activities of Korean red ginseng extract. Basic Clin Pharmacol Toxicol 2007;100:170-175.

5. Kwak YS, Kyung JS, Kim JS, Cho JY, Rhee MH. Antihyperlipidemic effects of red ginseng acidic polysaccharide from Korean red ginseng. Biol Pharm Bull
2010;33:468-472.

6. Wong VK, Cheung SS, Li T, Jiang ZH, Wang JR, Dong H, Yi XQ, Zhou H, Liu L. Asian ginseng extract inhibits in vitro and in vivo growth of mouse lewis lung carcinoma via modulation of ERK-p53 and NF- $\mathrm{B}$ signaling. J Cell Biochem 2010;111:899-910.

7. Kim CS, Park JB, Kim KJ, Chang SJ, Ryoo SW, Jeon BH. Effect of Korea red ginseng on cerebral blood flow and superoxide production. Acta Pharmacol Sin 2002;23:1152-1156.

8. Jeon BH, Kim CS, Kim HS, Park JB, Nam KY, Chang SJ. Effect of Korean red ginseng on blood pressure and nitric oxide production. Acta Pharmacol Sin 2000;21:10951100.

9. Nakajima S, Uchiyama Y, Yoshida K, Mizukawa H, Haruki $\mathrm{E}$. The effects of ginseng radix rubra on human vascular endothelial cells. Am J Chin Med 1998;26:365-373.

10. Kwok HH, Ng WY, Yang MS, Mak NK, Wong RN, Yue PY. The ginsenoside protopanaxatriol protects endothelial cells from hydrogen peroxide-induced cell injury and cell death by modulating intracellular redox status. Free Radic Biol Med 2010;48:437-445.

11. Jovanovski E, Jenkins A, Dias AG, Peeva V, Sievenpiper J, Arnason JT, Rahelic D, Josse RG, Vuksan V. Effects of Korean red ginseng (Panax ginseng C.A. Mayer) and its isolated ginsenosides and polysaccharides on arterial stiffness in healthy individuals. Am J Hypertens 2010;23:469472.

12. Sung J, Han KH, Zo JH, Park HJ, Kim CH, Oh BH. Effects of red ginseng upon vascular endothelial function in patients with essential hypertension. Am J Chin Med 2000;28:205-216.

13. Lee HJ, Lee YH, Park SK, Kang ES, Kim HJ, Lee YC, Choi CS, Park SE, Ahn CW, Cha BS et al. Korean red ginseng (Panax ginseng) improves insulin sensitivity and attenuates the development of diabetes in Otsuka LongEvans Tokushima fatty rats. Metabolism 2009;58:11701177.

14. Maines MD, Trakshel GM, Kutty RK. Characterization of two constitutive forms of rat liver microsomal heme oxygenase. Only one molecular species of the enzyme is inducible. J Biol Chem 1986;261:411-419.

15. McCoubrey WK Jr, Huang TJ, Maines MD. Isolation and characterization of a cDNA from the rat brain that encodes hemoprotein heme oxygenase-3. Eur J Biochem 1997;247:725-732.

16. Surh YJ, Kundu JK, Li MH, Na HK, Cha YN. Role of Nrf2-mediated heme oxygenase-1 upregulation in adaptive survival response to nitrosative stress. Arch Pharm Res 2009;32:1163-1176. 
17. Idriss NK, Blann AD, Lip GY. Hemoxygenase-1 in cardiovascular disease. J Am Coll Cardiol 2008;52:971-978.

18. Pae HO, Lee YC, Chung HT. Heme oxygenase- 1 and carbon monoxide: emerging therapeutic targets in inflammation and allergy. Recent Pat Inflamm Allergy Drug Discov 2008;2:159-165.

19. Baranano DE, Rao M, Ferris CD, Snyder SH. Biliverdin reductase: a major physiologic cytoprotectant. Proc Natl Acad Sci U S A 2002;99:16093-16098.

20. Deshane J, Wright M, Agarwal A. Heme oxygenase-1 expression in disease states. Acta Biochim Pol 2005;52:273284.

21. Durante W, Schafer AI. Carbon monoxide and vascular cell function (review). Int J Mol Med 1998;2:255-262.

22. Terry CM, Clikeman JA, Hoidal JR, Callahan KS. Effect of tumor necrosis factor-alpha and interleukin-1 alpha on heme oxygenase-1 expression in human endothelial cells. Am J Physiol 1998;274(3 Pt 2):H883-H891.

23. Kim YK, Guo Q, Packer L. Free radical scavenging activity of red ginseng aqueous extracts. Toxicology 2002;172:149-156.

24. Lee SH, Lee SE, Ahn HJ, Park CS, Cho JJ, Park YS. Identification of atherosclerosis related gene expression profiles by treatment of Benzo(a)pyrene in human umbilical vein endothelial cells. Mol Cell Toxicol 2009;5:113119.

25. Park YS, Kim J, Misonou Y, Takamiya R, Takahashi M, Freeman MR, Taniguchi N. Acrolein induces cyclooxygenase-2 and prostaglandin production in human umbilical vein endothelial cells: roles of p38 MAP kinase. Arterioscler Thromb Vasc Biol 2007;27:1319-1325.

26. Lee SE, Lee NJ, Lee SH, Park CS, Ahn HJ, Park YS. Uncaria rhynchophylla induces heme oxygenase-1 as a cytoprotective effect in RAW 264.7 macrophages. Mol Cell Toxicol 2010;6:33-40.

27. Kobayashi M, Yamamoto M. Molecular mechanisms activating the Nrf2-Keap1 pathway of antioxidant gene regulation. Antioxid Redox Signal 2005;7:385-394.

28. Aoki M, Nata T, Morishita R, Matsushita H, Nakagami H, Yamamoto K, Yamazaki K, Nakabayashi M, Ogihara T, Kaneda Y. Endothelial apoptosis induced by oxidative stress through activation of NF-kappaB: antiapoptotic effect of antioxidant agents on endothelial cells. Hypertension 2001;38:48-55.

29. Nam KY. The comparative understanding between red ginseng and white ginsengs, processed ginsengs (Panax ginseng C. A. Meyer). J Ginseng Res 2005;29:1-18.

30. Yang SJ, Woo KS, Yoo JS, Kang TS, Noh YH, Lee JS, Jeong HS. Change of Korean ginseng components with high temperature and pressure treatment. Korean J Food Sci Technol 2006;38:521-525.

31. Hien TT, Kim ND, Kim HS, Kang KW. Ginsenoside Rg $_{3}$ inhibits tumor necrosis factor-alpha-induced expression of cell adhesion molecules in human endothelial cells. Pharmazie 2010;65:699-701.

32. Min JK, Kim JH, Cho YL, Maeng YS, Lee SJ, Pyun BJ, Kim YM, Park JH, Kwon YG. 20(S)-Ginsenoside $\mathrm{Rg}_{3}$ prevents endothelial cell apoptosis via inhibition of a mitochondrial caspase pathway. Biochem Biophys Res Commun 2006;349:987-994.

33. He F, Guo R, Wu SL, Sun M, Li M. Protective effects of ginsenoside $\mathrm{Rb}_{1}$ on human umbilical vein endothelial cells in vitro. J Cardiovasc Pharmacol 2007;50:314-320.

34. Leung KW, Pon YL, Wong RN, Wong AS. Ginsenoside$\mathrm{Rg}_{1}$ induces vascular endothelial growth factor expression through the glucocorticoid receptor-related phosphatidylinositol 3-kinase/Akt and beta-catenin/T-cell factordependent pathway in human endothelial cells. J Biol Chem 2006;281:36280-36288.

35. Lee SK, Lee JW, Do JH, Shim KH. Water soluble browning pigments of Korean red ginseng (Panax ginseng C.A. Meyer). Korean J Ginseng Sci 1995;19:244-248.

36. Lee JW, Park CK, Do JH. Antioxidative activity of the water soluble browning reaction products from Korean red ginseng. J Ginsng Res 2005;29:44-48.

37. Gozzelino R, Jeney V, Soares MP. Mechanisms of cell protection by heme oxygenase-1. Annu Rev Pharmacol Toxicol 2010;50:323-354.

38. Deramaudt BM, Braunstein S, Remy P, Abraham NG. Gene transfer of human heme oxygenase into coronary endothelial cells potentially promotes angiogenesis. J Cell Biochem 1998;68:121-127.

39. Kim YM, Pae HO, Park JE, Lee YC, Woo JM, Kim NH, Choi YK, Lee BS, Kim SR, Chung HT. Heme oxygenase in the regulation of vascular biology: from molecular mechanisms to therapeutic opportunities. Antioxid Redox Signal 2011;14:137-167.

40. Hwang YP, Jeong HG. Ginsenoside $\mathrm{Rb}_{1}$ protects against 6-hydroxydopamine-induced oxidative stress by increasing heme oxygenase-1 expression through an estrogen receptor-related $\mathrm{PI} 3 \mathrm{~K} / \mathrm{Akt} / \mathrm{Nrf} 2$-dependent pathway in human dopaminergic cells. Toxicol Appl Pharmacol 2010;242:18-28.

41. Park SH, Jang JH, Chen CY, Na HK, Surh YJ. A formulated red ginseng extract rescues $\mathrm{PC} 12$ cells from $\mathrm{PCB}-$ induced oxidative cell death through Nrf2-mediated upregulation of heme oxygenase-1 and glutamate cysteine ligase. Toxicology 2010;278:131-139. 